\title{
COVID-19 DAN PENGARUHNYA TERHADAP PERILAKU HIDUP BERSIH MASYARAKAT MUSLIM
}

\author{
Amrullah \\ Universitas Gadjah Mada Yogyakarta \\ amrullah2019@mail.ugm.ac.id \\ Hasse Jubba \\ Universitas Muhammadiyah Yogyakarta \\ hasse@umy.ac.id \\ Siti Maysharah \\ Universitas Gadjah Mada Yogyakarta \\ maysarah667@gmail.com
}

\begin{abstract}
ABSTRAK
Coronavirus disease atau Covid-19 memaksa masyarakat untuk berubah dan menyesuaikan diri dalam rangka menghadapi dan menghentikan penyebarannya. Menjaga kebersihan diri serta lingkungan adalah salah satu cara yang dianjurkan WHO dan pemerintah untuk dilakukan dalam upaya penanganan tersebut. Jauh-jauh hari, Islam telah mengajarkan mengenai keutamaan kebersihan dalam Al-Quran dan hadis. Begitupun dengan otoritas keagaamaan seperti MUI telah mengeluarkan fatwa akan hal tersebut, jauh sebelum virus corona masuk ke Indonesia. Penelitian ini dengan menggunakan metode studi pustaka, mencoba memahami kesadaran masyarakat Muslim terhadap kebersihan dan efek dari Covid-19 terhadap perilaku kebersihan tersebut. Ditemukan bahwa idealitas yang diharapkan agama Islam untuk sadar akan kebersihan masih menunjukkan gap atas realitas yang terjadi, khususnya di Indonesia, sebagai negara dengan penduduk muslim terbesar di dunia. Namun masuknya pandemi Covid-19 ke Indonesia membawa dampak positif terhadap perilaku kebersihan. Berdasarkan survey dari BPS, mayoritas responden menjadi lebih sering menerapkan perilaku kebersihan. Selain itu ormas-ormas Islam seperti MUI, Muhammadiyah dan NU sedari awal telah memperlihatkan komitmennya terhadap pentingnya menjaga kebersihan diri serta lingkungan. Salah satu hikmah dari pandemi Covid-19 adalah meningkatkan kesadaran masyarakat atas kebersihan, khususnya dalam kehidupan sehari-hari.
\end{abstract}

Kata Kunci: Covid-19, Kebersihan, Muslim, Islam 


\begin{abstract}
Coronavirus disease also known as Covid-19 forces society to adapt and change to encounter and stop its spread. Maintaining personal and environmental cleanliness is the method suggested by WHO and the government for dealing with the pandemic. Islam has taught about the virtue of cleanliness in the Quran and hadith long before the Covid-19 pandemic. Likewise, religious authorities such as the MUI issued a fatwa on the topic long before the coronavirus arrived in Indonesia. This research used the literature review method to understand Muslim society's awareness of cleanliness and the impact of Covid-19 on its behaviors. It discovered that the ideal expected of Islam to be aware of cleanliness still showed a gap over the reality that occurred, particularly in Indonesia, which has the world's largest Muslim population. However, the arrival of the Covid-19 pandemic in Indonesia has had a positive impact on personal cleanliness. According to a BPS survey, the majority of respondents are more likely to adopt hygiene behavior. Furthermore, Islamic organizations such as MUI, Muhammadiyah, and NU have long emphasized the importance of maintaining personal and environmental cleanliness. One of the lessons of the Covid-19 pandemic is the importance of cleanliness, particularly in daily life.
\end{abstract}

Keywords: Covid-19, Cleanliness, Moslem, Islam

\title{
A. PENDAHULUAN
}

Coronavirus disease atau yang kemudian dikenal dengan Covid-19 telah bertransformasi menjadi salah satu wabah penyakit berbahaya di dunia abad ini yang disebabkan oleh infeksi virus corona. Muncul pertama kali sebagai kasus lokal di Kota Wuhan, China akhir tahun 2019, selanjutnya menyebar ke seluruh dunia dan menjadi pandemi yang mematikan. Organisasi Kesehatan Dunia (WHO) melaporkan bahwa kasus Covid-19 pertama yang dikonfirmasi di China adalah pada 8 Desember 2019. Setelah kasus yang pertama tersebut, bermunculan kasus lain dan terus menyebar bahkan ke hampir seluruh negara di dunia, hingga kemudian pada 30 Januari 2020 WHO menetapkan kejadian ini sebagai darurat kesehatan masyarakat global (Baskara, 2020). Hingga dengan 14 Juni 2020, WHO melaporkan secara keseluruhan tercatat sebanyak 7.690.708 kasus terkonfirmasi positif Covid-19 dan sejumlah 427.630 kasus meninggal dunia (WHO, 2020)

Kasus pertama Covid-19 di Indonesia secara resmi dilaporkan oleh Presiden Joko Widodo pada tanggal 2 Maret 2020. Dua warga negara Indonesia yang terkonfirmasi positif Covid-19 tersebut sebelumnya melakukan kontak dengan warga negara Jepang yang tiba di Indonesia (Baskara, 2020). Sebagaimana berlangsung secara global, dari satu kasus yang ada kemudian terus-menerus muncul kasus yang lain, pun dengan akibat kematian yang ditimbulkannya. Pemerintah melalui Badan Nasional Penanggulangan Bencana (BNPB) selanjutnya menetapkan status masa darurat wabah penyakit akibat virus corona di Indonesia selama 91 hari, terhitung sejak tanggal 29 Februari 2020 hingga dengan tanggal 29 Mei 2020 (Koesmawardhani, 2020). Kasus 
kematian pertama akibat Covid-19 yang dialami oleh WNI terjadi pada 11 Maret 2020 (Baskara, 2020). Kasus baru terus bermunculan setiap hari, Gugus Tugas Percepatan Penanganan Covid-19 mendata per 14 Juni 2020 jumlah kasus positif di Indonesia yakni 38.277 kasus, 14.531 di antaranya dinyatakan sembuh dan 2.134 meninggal dunia (Covid19.go.id, 2020).

Tidak dapat dipungkiri lagi bahwa fenomena Covid-19 telah menimbulkan dampak yang sangat besar secara global. Tidak hanya menyebabkan kematian saja sebagaimana telah dijabarkan di atas, namun juga membawa pengaruh yang signifikan ke segala lini kehidupan manusia. Dunia dipaksa untuk menyesuaikan diri dengan fenomena ini dalam rangka memutus mata rantai penyebarannya, apa lagi karena hingga saat ini vaksin untuk Covid19 belum ditemukan. Pemerintah sendiri sejak awal telah mensosialisasikan kampanye gerakan social distancing untuk mencegah penularan dan menekan angka kasus positif. Kemudian himbauan tersebut dipertegas dengan penerapan Pembatasan Sosial Berskala Besar (PSBB) melalui Peraturan Pemerintah Nomor 21 Tahun 2020 yang diteken oleh Presiden pada 31 Maret 2020 (JDIH $B P K R I]$, 2020).

Dalam rangka mencegah penularan Covid-19 serta menekan pertumbuhan kasus positif serta kematian yang disebabkan, beberapa upaya bersama oleh pemerintah dan masyarakat telah dilakukan. Selain melalui kebijakan PSBB itu tadi, masyarakat juga dihimbau untuk senantiasa menjaga kesehatan serta kebersihan diri misalnya denganmakan makanan sehat dan rajin mencuci tangan. Agar melindungi diri serta orang lain dari penyebaran Covid-19, WHO menyarankan untuk senantiasa menjaga kebersihan tangan dengan mencucinya secara teratur dan menyeluruh menggunakan air bersih dan sabun (WHO, 2020). Senada dengan hal tersebut, himbauan serupa juga tertera dalam Pedoman Pencegahan serta Pengendalian Corona virus Disesase yang diterbitkan oleh Kementerian Kesehatan RI. Berkaitan dengan kebersihan, pedoman tersebut juga menghimbau masyarakat untuk menjalankan prosedur pembersihan dan disinfeksi lingkungan dengan benar dan konsisten. Diantaranya meliputi menjaga kebersihan permukaan barang atau perabotan, kebersihan toilet dan kamar mandi, kebersihan pakaian, seprei, handuk dan sejenisnya, membuang sampah di TPA, serta mengenakan sarung tangan sekali pakai saat membersihkan (Kemkes $R I, 2020$ ).

Kebersihan merupakan salah satu aspek yang sangat penting dalam kehidupan sehari-hari, dan kemunculan Covid-19 seolah-olah menjadi momen untuk mengingatkan kembali manusia akan hal tersebut. Berbicara mengenai kebersihan, sebetulnya ajaran agama seperti Islam sudah jauh-jauh hari membicarakan mengenai keutamaannya untuk dilaksanakan. Di dalam sumber utama ajaran Islam, yakni Al-Quran dan hadis, ada banyak tuntunan yang membahas mengenai keutamaan menjaga kesucian diri berupa kebersihan jasmani dan rohani. Sebagai negara dengan penduduk mayoritas Muslim terbesar di dunia, menarik untuk memahami bagaimana kesadaran masyarakat di Indonesia mengenai kebersihan, serta dampak dari Covid-19 terhadap pola hidup bersih masyarakat. Tujuan dari artikel ini adalah untuk mengetahui tentang Penerapan kebersihan yang diajarkan Islam yang tertuang dalam Qur'an dan Hadits sebelum munculnya Virus Corona.

Penelitian terdahulu yang hampir mirip dengan artikel ini diantaranya adalah: R.A.W. Irham, A.K. Siregar, \& H. Jubba (2020), mengatakan: Umat 
Islam meyakini pandemic ini berasal dari Allah SWT, namun umat Islam diharapkan tidak terlalu menanggapinya serta menjadikan fenomena tersebut agar menambah modal taqwa pada Allah SWT Tuhan Yang Maha Esa., fiqih Islam mampu membantu mencarikan solusi dalam mengatasi Pandemi Covid19. Pemerintah yang merupakan pemimpin di negeri ini telah menerapkan kebijakan terkait pengurangan Covid-19. Banyak pihak yang menanggapi kebijakan yang ditetapkan pemerintah tidak percaya juga karena menentang pemerintah disebabkan minimnya pendidikan oleh pemerintah dan tokoh agama.

M. Wahyu Pratama Putra \& Kurnia Sari Kasmiarno (2020), mengatakan: Pada sector pendidikan terdapat system daring, dengan dampak yang kurang efektif. Sedangkan disektor ekonomi merubah masyarakat lebih kreatif, akan tetapi tetap berdampak pada turunnya pendapatan. Disisi spiritual keagamaan membentuk aktivitas keagamaan beradaptasi pada keadaan, yang berdampak pada aktivitas agama di rumah, secara live streming, dan lain-lain. Selain itu, trauma yang diterima dalam bentuk rasa takut tertular virus Covid-19. Akan tetapi mereka tetap survive melalui belajar mandiri, menekan biaya pengeluaran serta meningkatkan ibadah. Hikmah yang didapatkan atas pandemic ini yaitu lebih sering berkumpul dengan keluarga, semakin kreatif, khusyuk dalam beribadah serta terbentuknya jiwa saling membantu.

Inayati, et.al (2021), mengatakan: Menunjukkan bahwa social distancing sebagian besar telah diketahui serta dipahami oleh masyarakat kampung Bebon Jaya sebagai strategi pencegahan penyebaran Covid-19, akan tetapi masih terdapat sebagian warga masyarakat yang melawan aturan dalam wujud protocol kesehatan yang sudah ditetapkan oleh Pemerintah serta dinas yang berwenang, pembatasan kegiatan warga, aturan yang mewajibkan dilakukannya social distancing, serta kelalaian masyarakat pada pelaksanaan social distancing, juga sanksi atas pelanggaran di masa pandemic Covid-19, yang merupakan konsekwensi kesepakatan bersama oleh warga agar tetap beraktifitas yang ditimbulkan akibat kejenuhan warga.

Perbedaan dengan penelitian tersebut di atas terletak pada penerapan kebersihan yang diajarkan Islam yang tertuang dalam AL-Qur'an dan Hadits sebelum munculnya Virus Corona.

Jenis penelitian yang digunakan dalam tulisan ini merupakan penelitian kualitatif dengan jenis deskriptif. Pendekatan deskriptif kualitatif oleh Soekanto (2016) disebutkan sebagai sebuah upaya proses memecahkan masalah dengan menggambarkan keadaaan suatu subjek atau objek. Metode yang digunakan adalah studi kepustakaan, yakni studi yang objek penelitiannya dalam bentuk karya-karya kepustakaan baik berupa jurnal ilmiah, buku, artikel pada media massa, atau data-data statistika. Dengan metode tersebut, penulis memaparkan mengenai topik permasalahan penelitian yakni bagaimana kesadaran masyarakat muslim terhadap kebersihan serta pengaruh Covid-19 mengenai perilaku hidup bersih masyarakat muslim, dengan mengambil contoh kasus di Indonesia.Jenis data yang digunakan adalah data sekunder, dan proses analisis data menggunakan model Miles dan Huberman dikutip Andi Bugis, et.al (2020) yang mengandung tiga komponen, yakni data reduction, data display, dan conclusion drawing/verification. 


\section{B. KEBERSIHAN DALAM ISLAM}

Di dalam Islam, kebersihan dipandang dari dua sisi, yaitu kebersihan jasmani dari berbagai najis serta kebersihan rohani dari berbagai dosa (MUI, 2015). Menjaga kebersihan sangatlah penting, bahkan saking pentingnya sehingga orang yang membersihkan diri atau mengusahakan kebersihan akan dicintai oleh Allah SWT. Di dalam al-Quran dikatakan:

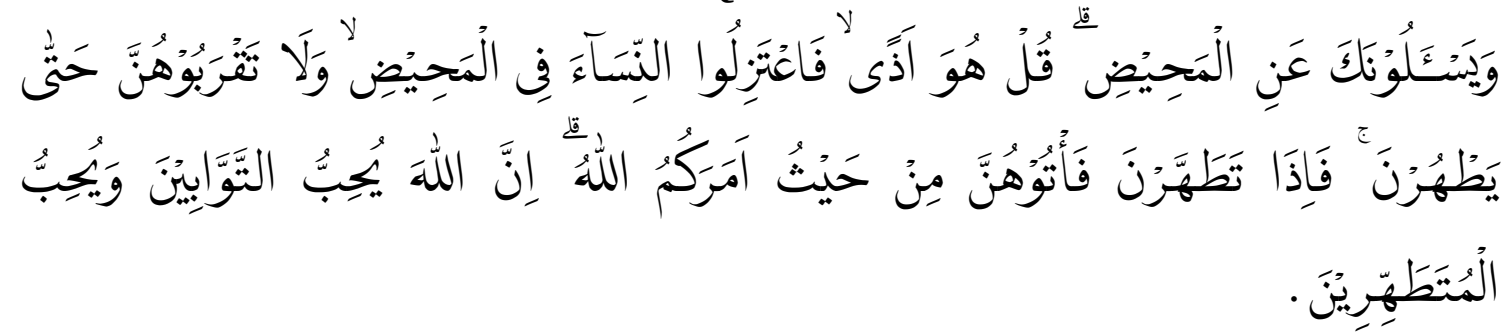

Terjemahannya:

"Mereka bertanya kepadamu (Nabi Muhammad) tentang haid. Katakanlah, "Itu adalah suatu kotoran." Maka, jauhilah para istri (dari melakukan hubungan intim) pada waktu haid dan jangan kamu dekati mereka (untuk melakukan hubungan intim) hingga mereka suci (habis masa haid). Apabila mereka benar-benar suci (setelah mandi wajib), campurilah mereka sesuai dengan (ketentuan) yang diperintahkan Allah kepadamu. Sesungguhnya Allah menyukai orang-orang yang bertobat dan menyukai orang-orang yang menyucikan diri”. (QS. AlBaqarah [2]: 222).

Kebersihan dalam agama Islam adalah konseskuensi dari keimanan kepada Allah, Tuhan Yang Maha Suci. Ia menjadi pangkal atau bagian tak terpisahkan dari keimanan seorang muslim sebagai jalan agar mendekatkan diri kepada Allah Yang Maha Suci. Nabi SAW menegaskan hal tersebut dalam hadis:

"Kebersihan itu adalah separuh dari iman" (H.R. Muslim)

"Iman itu lebih dari 60 cabang. Seutama-utamanya iman adalah ucapan lailaha illallah dan serendah-rendahnya iman adalah membuang kotoran dari jalan raya" (H.R. Al-Bukhari)

Hadis-hadis di atas menunjukkan bahwa kebersihan merupakan bersumber dari iman serta merupakan bagian dari iman. Sehingga kebersihan dalam ajaran Islam mengandung aspek ibadah serta juga aspek moral. Karena itu pula maka kata bersuci sering dipakai sebagai padanan kata untuk membersihkan atau melaksanakan kebersihan.

Perintah mengenai kebersihan bukan hanya berhenti sebagai slogan atau teori semata, namun hendaknya mampu teraplikasi secara praktis sebagai pola hidup. Di dalam Islam, kebersihan terlembagakan dalam hukum atau syariat agama sehingga kemudian dikenal beberapa sarana kebersihan yang tergolong sebagai ibadah. Misalnya seperti wudhu', tayamum, mandi ( $g$ husl), bersiwak (pembersihan gigi), membersihkan hadas dan najis, dan lain-lain (MUI, n.d). Bahkan perintah untuk menjaga kebersihan dalam pola hidup sudah di mulai dari ketika bangun tidur. Nabi SAW bersabda:

"Apabila salah seorang diantara kamu bangun dari tidur, maka janganlah memasukkan tanganmu ke dalam bejana sebelum ia 
mencucinya tiga kali. Maka sesungguhnya ia tidak tahu ke mana tangannya itu pada waktu ia tidur" (H.R. Al-Bukhari dan Muslim).

Selain itu terdapat pula perintah shalat, baik yang sifatnya wajib maupun sunnah, yang mana harus dimulai dengan wudhu' terlebih dahulu serta salah satu syarat sahnya adalah dengan menjamin kebersihan/kesucian badan, pakaian, dan tempat sholat. Ini menunjukkan bahwa ibadah dalam Islam, dalam hal ini sholat, mensyaratkan jaminan terhadap kebersihan diri, pakaian, serta lingkungan bagi mereka yang melakukannya. Maka dari itu hidup bersih hendaknya merupakan sikap dan budaya hidup di lingkungan serta masyarakat muslim. Bersabda Nabi Muhammad SAW:

"Jagalah kebersihan dengan segala usaha yang dapat kamu lakukan. Sesungguhnya Allah menegakkan Islam di atas prinsip kebersihan. Dan tak akan memasuki syurga kecuali orang-orang yang memelihara kebersihan" (H.R. Ath-Thabrani).

Di dalam kitab-kitab fikih, masalah yang berkaitan dengan kebersihan dikatan dengan thaharah. Makna thaharah meliputi aspek bersih lahir serta bersih bathin. Bersih lahir memiliki arti terhindar (terlepas) pada berbagai kotoran, hadas serta najis. Sedangkan bersih bathin didefinisikan terhindar dari sikap serta sifat tercela. Di dalam Al-Quran, Allah SWT menjelaskan mengenai kebersihan (thaharah) sebanyak 33 kali. Ayat tersebut berkaitan kebersihan jasmani atau badan (Al-Maiddah [5]:6; Al-A'laa [87]:14-15), kebersihan rohani (Al-Anfaal [8]: 2; At-Taubah [9]:108; Al-Ahzab[33]:33) kebersihan tempat (AtTaubah [9]:108), kebersihan pakaian (Al-Muddatsir [74]:l-5), kebersihan makanan (Al-Baqarah [2]:172 \& 168; Al-Maaidah [5]:3 \& 90), kebersihan lingkungan (Ar-Ruum [30]:41; Al-Qashash [28]: 77), kebersihan dalam keluarga (Al-Baqarah [2]: 222; At-Tahrim [66]: 6), kebersihan harta (At-Taubah [9]: 103) dan lain sebagainya(MUI, 2015).

\section{KESADARAN MUSLIM TERHADAP KEBERSIHAN: IDEALITAS DAN REALITAS}

Sebelum pandemi Covid-19 muncul dan kemudian semua orang dihimbau untuk selalu menjaga kebersihan, sebetulnya jauh-jauh hari masyarakat terutama dalam hal ini umat muslim, sudah memiliki kesadaran akan kebersihan. Misalnya saja kitab-kitab klasik cendekiawan muslim yang membahas mengenai fikih, selalu diawali dengan bab pembahasan thaharahatau bersuci/ membersihkan diri. Di Indonesia sendiri, sebagai negara dengan jumlah populasi muslim terbesar di dunia berdasarkan Pew Research Center (2011), terdapat beberap bukti bahwa kesadaran akan kebersihan sudah ada sebelum datangnya Covid-19. Misalnya Muktamar Nahdlatul Ulama tahun 1994 yang menyerukan jihad lingkungan hidup dan menyatakan haram terhadap tindakan pencemaran lingkungan (Muhammadun, 2015). Majelis Ulama Indonesia (MUI) mengeluarkan Fatwa No. 41 Tahun 2014 tentang Pengelolaan Sampah agar Mencegah Kerusakan Lingkungan yang mewajibkan menjaga kebersihan dan mengharamkan membuang sampah sembarangan (MUI, 2014). 
Idealitas konsep Islam terhadap kebersihan beserta ajakan untuk melaksanakannya dalam kehidupan ternyata terkadang tidak sesuai dengan realitas praktek masyarakat. Dari data riset Kementerian Kesehatan diketahui terdapat $20 \%$ dari total keseluruhan masyarakat Indonesia yang peduli pada kebersihan serta dampaknya terhadap kesehatan. Berdasarkan laporan Riskesdas, terdapat 59,8 rumah tangga yang mempunyai akses pada fasilitas sanitasi yang sesuai standar. Selain itu, pola atau kebiasaan higienitas yang baik seperti sikat gigi serta cuci tangan juga masih belum dilaksanakan seluruh masyarakat Indonesia (Litbang Kemendagri, 2018). Kesadaran yang rendah ini tentunya sangat mengkhawatirkan, mengingat kebersihan berpengaruh besar terhadap kesehatan. Sehingga terlihat bahwa masih ada gap antara kondisi ideal yang diinginkan oleh agama dengan kenyataan yang terjadi di masyarakat.

\section{COVID-19 DAN PERUBAHAN KESADARAN MUSLIM AKAN KEBERSIHAN}

Untuk melihat pengaruh pandemi Covid-19 terhadap perilaku masyarakat, termasuk mengenai kebersihan, dapat diketahui dari hasil survei yang dilaksanakan oleh lembaga-lembaga yang kredibel. Survey yang dilaksanakan oleh Harris Interactive dan RB terhadap 11.00o orang dewasa di 11 negara (Australia, China, Jerman, India, Jepang, Malaysia, Arab Saudi, Afrika Selatan, Thailand, Inggris, dan AS) menunjukkan bahwa $76 \%$ responden mengerti bahwa mereka dapat melindungi diri dengan kebersihan yang baik. Survei tersebut terlaksana dari 6 sampai 11 Februari 2020 secara online, dan dari hasilnya diketahui bahwa terjadi perubahan perilaku yang positif akibat Covid-19 seperti 54\% responden lebih sering mencuci tangan dan 41\% lebih sering memakai hand-sanitazer, serta $23 \%$ lebih sering mendisinfeksi permukaan barang sejak pandemi. Berikut ini rincian persentase responden yang menyatakan lebih sering mencuci tangan berdasarkan negara ( $R B, 2020)$

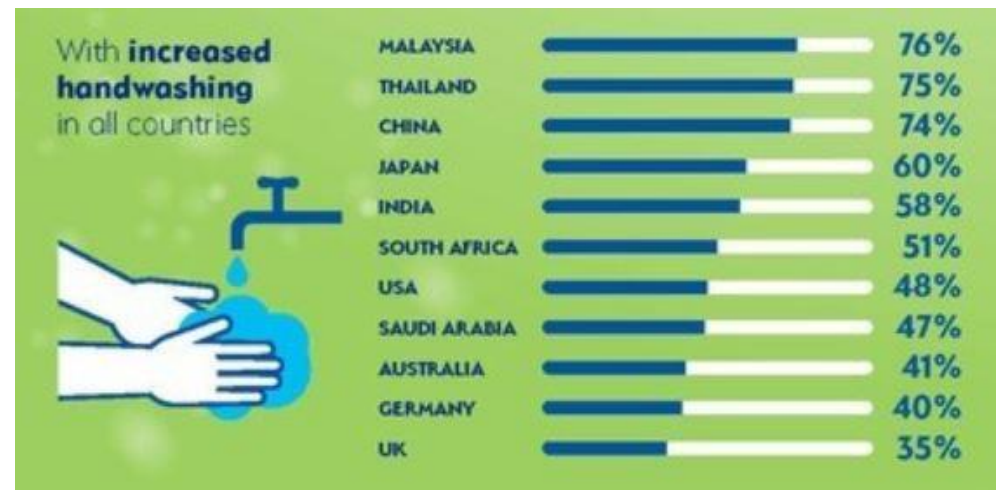

Gambar 1. Persentase Kenaikan Perilaku Mencuci Tangan Selama Covid-19

Sumber: www.prnewswire.co.uk

Terlihat bahwa negara-negara yang letaknya lebih dekat dengan asal mula Covid-19 seperti Malaysia, Thailand, China, Jepang dan India menunjukkan bahwa peningkatan kebiasaan cuci tangan di sana lebih besar 
ketimbang di negara yang lain. Akan tetapi belum bisa dilihat apakah ada korelasi antara status agama dengan perubahan tersebut.

Untuk di Indonesia sendiri, kondisi dan perilaku perilaku masyarakat bisa diketahui dari survei yang telah dilaksanakan oleh Badan Pusat Statistik RI bertajuk Hasil Survei Sosial Demografi Dampak Covid-19. Di sana juga bisa ditemukan mengenai tingkat kesadaran masyarakat Indonesia akan kebersihan di tengah pandemi ini. Survei oleh BPS berbasis daring dan dilaksanakan pada 13-20 April 2020, dan diikuti sebanyak 87.379 responden. Adapun hasilnya dapat dilihat pada gambar di bawah ini (BPS, 2020).

\section{8 dari 10 responden sering/selalu mencuci tangan dengan sabun selama 20 detik.}

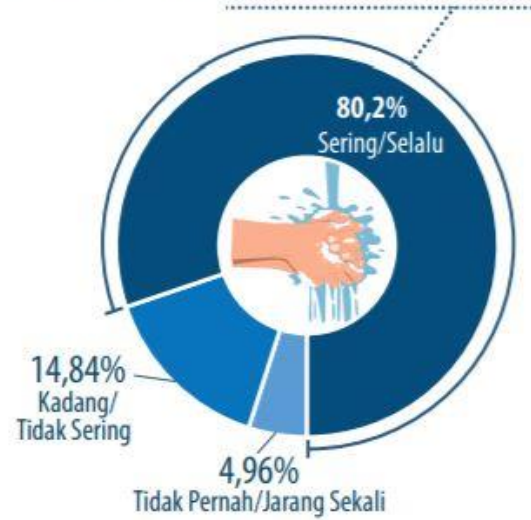

\section{Gambar 2. Persentase Responden Menurut Perilaku Mencuci Tangan Selama 20 Detik Dengan Sabun Sumber: BPS RI}

Dari data di atas terlihat bahwa kesadaran masyarakat Indonesia untuk selalu atau sering menjaga kebersihan tangan melalui cuci dengan sabun selama 20 detik selama pandemi Covid-19 sangat tinggi, mencapai 80,2\% dari responden.

\section{6 dari 10 responden sering/selalu menggunakan hand sanitizer.}

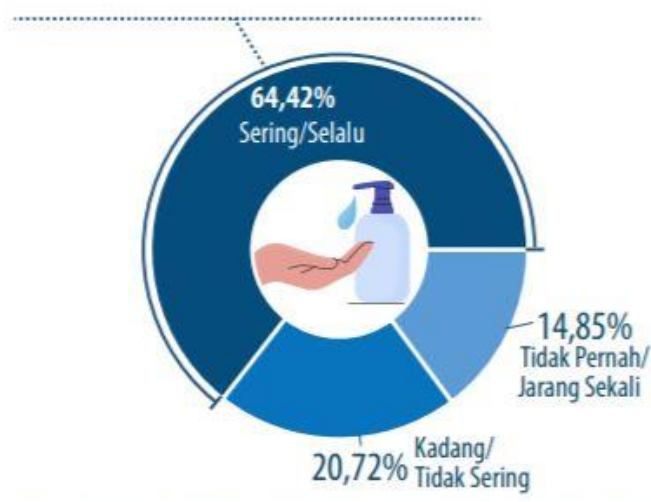

\section{Gambar 3. Persentase Responden Menurut Perilaku Penggunaan Hand-Sanitazer \\ Sumber: BPS RI}


Begitupun dengan penggunaan hand-sanitazer, jumlahnya cukup tinggi yakni $64,42 \%$ dari responden. Jumlah yang lebih sedikit ketimbang dengan sabun ini bisa disebabkan karena lebih sulit menemukan hand-sanitazer ketimbang sabun di setiap saat atau di setiap fasilitas umum (BPS, 2020).

Dari hasil survei yang dilakukan oleh BPS tersebut di atas, maka bisa dikatakan bahwa mayoritas masyarakat Indonesia sangat peduli dengan kebersihan, minimal dengan kebersihan tangan, selama masa pandemi Covid19. Walaupun tidak disebutkan data mengenai latar belakang agama responden, na mun bisa diasumsikan bahwa responden adalah mayoritas muslim didasarkan pada kenyataan bahwa Islam merupakan agama mayoritas yang dianut di Indonesia. Hasil Sensus Penduduk 2010 memperlihatkan bahwa dari 237,6 juta jiwa penduduk Indonesia, 207 juta lebih atau $87,18 \%$ adalah muslim (BPS, 2013).

Apabila ingin menelisik lebih jauh mengenai kesadaran umat Islam di Indonesia akan kebersihan sebagai dampak dari pandemi Covid-19, bisa dengan mengamati pernyataan, edaran, atau fatwa yang dikeluarkan oleh ormas-ormas besar Islam sebagai representasi sikap muslim Indonesia. Beberapa ormas yang bisa dijadikan patokan seperti Majelis Ulama Indonesia (MUI), Muhammadiyah dan Nahdlatul Ulama (NU). MUI sendiri telah mengeluarkan fatwa menyikapi keadaan pandemi Covid-19, terutama yang berkaitan dengan kelangsungan proses ibadah,melalui Fatwa MUI No. 14 Tahun 2020 tentang Penyelenggaran Ibadah dalam Situasi Terjadi Wabah Covid-19 (MUI, 2020). Dalam fatwa tersebut, MUI mewajibkan setiap individu untuk berikhtiar menjaga kesehatan serta menjauhi segala hal menyebabkan terpaparnya penyakit. Walau tidak secara spesifik menyebutkan, tetapi sudah pasti dengan ini MUI mewajibkan untuk melaksanakan segala bentuk pencegahan penyebaran virus corona, salah satunya dengan senantiasa menjaga kebersihan.

Muhammadiyah juga bergerak cepat menyikapi pandemi Covid-19 dan segera bersuara untuk menentukan sikap dan tindakan penanganan. Pimpinan Pusat Muhammadiyah mengeluarkan Surat Maklumat Nomor 02/MLM/I.o/H/2020 tentang Wabah Corona Virus Disease 2019. Salah satu poin isinya secara langsung menghimbau agar meningkatkan kebiasaan pola hidup sehat dengan menjaga kebersihan pribadi dan lingkungan serta mengikuti protokol pencegahan Covid-19 yang dikeluarkan oleh pemerintah. Searah dengan Muhammadiyah, NU juga secara resmi telah mengeluarkan beberapa surat edaran dan instruksi mengenai penanganan dan pencegahan Covid-19. Pengurus Besar NU mengeluarkan Surat Edaran bernomor 3953/C.I.o34/04/2020 yang menghimbau kepada masyarakat untuk senantiasa mentaati keputusan, kebijakan, serta himbauan pemerintah agar mencegah penyebaran Covid-19, tentunya dalam hal ini termasuk masalah menjaga kebersihan. Dengan demikian, sebagai representasi umat Islam di Indonesia, MUI, Muhammadiyah dan NU telah menunjukkan komitmen untuk bersamasama berjuang melawan Covid-19, termasuk dengan selalu menjaga kebersihan diri dan lingkungan. 


\section{E. KESIMPULAN}

Pandemi Covid-19 yang sedang merupakan kenyataan yang harus diterima dan dihadapi sebagai ujian dari Allah SWT untuk kemudian diambil hikmahnya. Ada banyak pelajaran yang bisa diambil dari pandemi ini, salah satunya adalah menjadi sarana untuk mengingatkan kembali masyarakat muslim akan mutiara ajaran agama yang kadang terabaikan dalam kehidupan sehari-hari: kebersihan. Walaupun ajaran agama Islam tentang keutamaan menjaga kebersihansudah sangat banyak di bahas dalam Al-Quran dan hadis, disertai himbauan-himbauan dari otoritas keagamaan setempat, namun nyatanya riset membuktikan bahwa kesadaran masyarakat mengenai kebersihan masih sangat rendah. Terutama di Indonesia yang menjadi rumah bagi komunitas muslim terbesar di dunia. Kehadiran Covid-19 bisa dikatakan menjadi pemicu masyarakat untuk kembali peduli dengan kebersihan. Survei dari BPS memperlihatkan bahwa mayoritas responden semakin peduli dengan perilaku kebersihan sejak datangnya pandemi. Tentu saja diharapkan kesadaran ini terus terpelihara dan dilaksanakan baik ada atau tidaknya pandemi.

\section{REFERENSI}

Baskara, B. (2020). Rangkaian Peristiwa Pertama Covid-19. Kompas. Accessed: 14/o6/2020. Retrieved from https://bebas.kompas.id/baca/riset/2020/ 04/18/rangkaian-peristiwa-pertama-covid-19/

BPS (2013). Penduduk Indonesia Hasil Sensus Penduduk 2010. Jakarta: Badan Pusat Statistik.

- (2020). Hasil Survey Sosial Demografi Dampak Covid-19. Accessed: 14/06/2020. Retrieved from https://www.bps.go.id/publication/ 2020/06/01/669cb2e8646787e52dd171c4/hasil-survey-sosial-demografi -dampak-Covid-19.html

Fatwa Majelis Ulama Indonesia Nomor 14 Tahun 2020 Penyelenggaran Ibadah Dalam Situasi Terjadi Wabah Covid-19. 16 Maret 2020. Majelis Ulama Indonesia Komisi Fatwa. Jakarta.

Gugus Tugas Percepatan Penanganan COVID-19 (2020). Peta Sebaran. Covid19.go.id. Diakses pada tanggal 14 Juni 2020. Dapat diakses di https://covid19.go.id/peta-sebaran

Irham, RAW, Siregar, AK, \& Jubba, H. (2020). Dampak Wabah Corona Virus Disease Terhadap Budaya Ibadah Umat Muslim Dan Kebijakan Pemerintah. POROS ONIM: Jurnal Sosial Keagamaan, 1(2), 131-143. https://doi.org/10.53491/poros onim.v1i2.34.

Keputusan Menteri Kesehatan Republik Indonesia. (2020).

Koesmawardhani, N.W. (2020, Maret 17)."Pemerintah Tetapkan Masa Darurat Bencana Corona hingga 29 Mei 2020”. DetikNews. Diakses pada tanggal 14 Juni 2020. Dapat diakses di https://news.detik.com/berita/d4942327/pemerintah-tetapkan-masa-darurat-bencana-corona-hingga29-mei-2020 
Litbang Kemendagri (2018). Riset: Kesadaran Masyarakat Indonesia akan Kebersihan Masih Rendah. Badan Penelitian Dan Pengembangan Kementerian Dalam Negeri. Diakses pada tanggal 14 Juni 2020. Dapat diakses di https://litbang.kemendagri.go.id/website/riset-kesadaranmasyarakat-indonesia-akan-kebersihan-masihrendah/\#: :text=Riset\%3A\%20Kesadaran\%20Masyarakat\%2oIndonesia \%20akan\%2oKebersihan\%20Masih\%2oRendah,ternyata\%2otak\%2oped uli\%20akan\%2okebersihan.\&text=Ini\%2oberarti\%2C\%20dari\%20262\% 20juta,sekitar\%2odan\%2odampaknya\%2oterhadap\%2okesehatan

Majelis Ulama Indonesia. (2014). Pengelolaan Sampah untuk Mencegah Kerusakan Lingkungan. Himpunan Fatwa MUI, 1-19.

Muhandy, R. S., Rohmah, M. N., Yusuf, M., \& Iribaram, S. (2021). Potret Penerapan Sosial Distancing Dalam Memutus Rantai Covid-19: Portrait Of The Application Of Social Distancing In Breaking The Covid-19. Jurnal Sosial Humaniora, 12(2), 126-138.

Majelis Ulama Indonesia (2015).Air, Kebersihan, Sanitasi dan Kesehatan Lingkungan menurut Agama Islam. Jakarta: Sekolah Pascasarjana Universitas Nasional

Muhammadun (2015). Muktamar 1994 dan Jihad Lingkungan Hidup. NU Online. Diakses: 14 Juni 2020. Dapat diakses di https://www.nu.or.id/post/read/64225/muktamar-1994-dan-jihadlingkungan-hidup

Pew Research Center (2011). The Future of the Global Muslim Population. Pew Research Center.Diakses pada tanggal 14 Juni 2020. Dapat diakses di https://www.pewforum.org/2011/o1/27/the-future-of-the-globalmuslim-population/

Peraturan Pemerintah Republik Indonesia Nomor 21 Tahun 2020 Pembatasan Sosial Berskala Besar Dalam Rangka Percepatan Penanganan Corona Wrus Disease 2019 (COVID-I9). 31 Maret 2020. Lembaran Negara Republik Indonesia Tahun 2020 Nomor 91. Jakarta.

Putra, M. W. P., \& Kasmiarno, K. S. (2020). Pengaruh Covid-19 Terhadap Kehidupan Masyarakat Indonesia: Sektor Pendidikan, Ekonomi Dan Spiritual Keagamaan. POROS ONIM: Jurnal Sosial Keagamaan, 1(2), 144-159. https://doi.org/10.53491/porosonim.v1i2.41

RB (2020). Survey Finds That 77 Percent of People Are Concerned About the Coronavirus Outbreak and 50 Percent Have Changed Hygiene Behaviours. Cision PR Newswire. Diakses pada tanggal 14 Juni 2020. Dapat diakses di https://www.prnewswire.co.uk/news-releases/surveyfinds-that-77-percent-of-people-are-concerned-about-the-coronavirusoutbreak-and-50-percent-have-changed-hygiene-behaviours804154176.html

Soekanto, S. (2016). Pengantar Penelitian Hukum. Jakarta: UI Press.

Surat Edaran Pengurus Besar Nahdlatul Ulama Nomor 3953/C.I.034/o4/2020 Surat Edaran. 3 April 2020. Pengurus Besar Nahdlatul Ulama. Jakarta .

Surat Maklumat Pimpinan Pusat Muhammdiyah Nomor 02/MLM/I.o/H/2020 Wabah Corona Virus Disease 2019 (COVID-19). 14 Maret 2020. Pimpinan Pusat Muhammdiyah. Yogyakarta. 
WHO (2020). WHO Coronavirus Disease (Covid-19) Dashboard. World Health Organization. Diakses pada tanggal 14 Juni 2020. Dapat diakses di https://covid19. who.int/?gclid=CjwKCAjwlZf3BRABEiwA8Qoqq91NpRy QMdTTkNwo5tZQXkogsxoeZYTFrDrG3OQLVol_kVJYzR5AKxoCFcoQA vD_BwE

WHO (2020). Coronavirus disease (Covid-19) advice for the public. World Health Organization. Diakses: 14 Juni 2020. Dapat diakses di https://www.who.int/emergencies/diseases/novel-coronavirus2019/advice-for-public

Yusuf, M. Y., et.al. (2020). The Rise Of Children Dropping Out Of School In Raja Ampat. AL-ISHLAH: Jurnal Pendidikan, 12(2), 270-287. https://doi.org/10.35445/alishlah.v12.i2.225 